\title{
A Consensus-Based Framework for the Sustainable Urban Planning Development: "As an Approach for Saudi Arabian Cities"
}

\author{
Ali AlQahtany, Yacine Rezgui, and Haijiang Li
}

\begin{abstract}
Cities in developing countries are experiencing rapid and in many cases unsustainable growth. This paper analyses the importance of sustainable urban planning in the context of the capital city of Saudi Arabia, which is Riyadh. It provides a comprehensive review of the historical growth of the city and critically discusses its urban planning development phases, informed by strategies and schemes adopted during this development process. This critical review is based on a proposed framework of sustainable development that focuses on a number of core issues, including environmental, social, economic and urban planning. This proposed model is evaluated based on the opinion of 35 experts, who are familiar with the local context of Saudi Arabian cities, through the use of the Delphi Technique.
\end{abstract}

Index Terms-Urban planning, sustainable urban planning development, oil boom phase, post-oil boom phase, Delphi Technique.

\section{INTRODUCTION}

Since its establishment 70 years ago the Kingdom of Saudi Arabia has been transformed into a modern, developing country [1]. This transformation has placed a great deal of pressure on many of the available resources, including oil and natural gas, and has introduced a number of serious issues, such as over-crowding and environmental degradation [2]. Therefore, sustainable urban planning has emerged as a pressing concern that must be addressed by both governments and city authorities alike [3]-[4]. The paper gives a comprehensive review of the current state of urban planning in Saudi Arabian cities and specifically within the capital city of Riyadh. The paper critically discusses some of the schemes that have been adopted such as Doxiadis and SCET schemes, informed by a proposed sustainable urban planning development model. Finally, the paper provides plans for future work and concluding remarks.

\section{RELATED RESEARCH}

There is a general consensus around the definition of Sustainable Development, i.e. "development that meets the needs of the present without compromising the ability of future generations to meet their own needs" [5]. The 1987

Manuscript received June 20, 2013; revised September 5, 2013.

A. AlQahtany is with the Cardiff School of Engineering, Cardiff University, Queen's Buildings, the Parade, Cardiff CF24 3AA, Wales UK (Alqahtany-ali@hotmail.com).

Y. Rezgui and H. Li are with the Engineering Informatics, Director BRE Institute in Sustainable Engineering, School of Engineering, Cardiff University (e-mail: rezguiy@Cardiff.ac.uk, lih@Cardiff.ac.uk).
Brundtland Commission and its report, Our Common Future, places the issue of the sustainable development at the core of the urban policy and planning concerns [6]. Sustainability in urban planning development has become a critical issue, due to high growth and urbanization in many parts of the world, and in particular in developing countries including Saudi Arabia [7]-[9].

The authors have discussed and critiqued a number of frameworks in respect of sustainable urban planning development: BREEAM Communities; CASBEE for Urban Development; and LEED for Neighborhood Development. These models have been applied in many academic articles to discuss key issues that are related to sustainable development [10]-[12]. Substantially, the authors argue that these frameworks have a number of strengths and weaknesses. On the one hand, they exhibit common concerns and emphasize the importance of various issues such as transport, energy, and resources [13]; on the other, these frameworks lack support or guidance for adaptation in other contexts (i.e. countries and regions). Additionally, they have overlooked the importance of the management and financial issues, where the emphasis on these issues is limited.

Hence, a sustainable urban planning development framework is proposed, and illustrated in Fig. 1. The objective is to be able to be adaptable to different places. The contribution of this proposed model is to propose a scalable framework for an effective sustainable urban planning development for communities that address the gaps and the limitations of the existing models. It takes into the account the core issues of urban communities including environmental, social, economic and planning perspectives.

The core of this framework has four dimensions, which must be integrated in order to achieve the desired goal of this proposal framework. Namely environmental, social, economic and planning dimension. Each one of them has a number of major categories in addition to a number of criteria. The model has an additional dimension, which is the information and communication technology dimension (ICT) that will be presented as an implicit dimension that will be included within all of the four key dimensions.

\section{Methodology}

The paper addresses the following research question: Can the growth of Riyadh City be managed sustainably through an adapted sustainable urban planning model? The paper reviews the historical urban development phases of Riyadh informed by the proposed model. The latter is then evaluated using a consensus-based approach: the Delphi Technique. This can be described as a team decision method, which 
needs skilled experts with profound knowledge of the issues [14]. There are diverse types of the Delphi Techniques that have been employed including Policy Delphi, Real-time Delphi and Decision Delphi [15], [16].



Fig. 1. The proposed model for sustainable urban planning development with the main dimensions, categories and criteria.

This paper makes use of the Delphi Technique to generate views regarding regions of sustainable urban planning development and to acquire the consent with regards to a group of categories and criteria. Thus, Decision Delphi approach has been followed in this paper. It consists of a team of decision-makers and professionals who are chosen in accordance with their position in the hierarchy of decision-makers and their proficiency. Okoli and Pawlowski [14], point out that traditional surveys experience richness issues while Delphi studies essentially supply richer data, due to their numerous iterations and feedback, where the experts taking part in Delphi are positive towards follow-up interviews. In Delphi Technique the participating experts are anonymous to everybody except the researcher.

This allows the researchers to contact them for additional explanations. Additionally, this research is concerned with determining the issues that are anticipated in promoting sustainable urban planning development in Saudi Arabia. This is a crucial matter and thus needs accurate knowledge from the highly experienced people who identify with the diverse environmental, social, economic, planning and political matters of the region. Another feature that makes Delphi popular is that experts do not have to get together in person, where it can be done through the use of online software, as this could be realistic for professionals from around the globe.

Throughout this study, the approach of "ranking-type" Delphi survey, proposed by Schmidt [17], is considered for the organization of the questionnaires, data collection and investigation of the information. This method has been referred to in numerous scientific papers [14], [18], [19]. It is derived from the distribution of the process of the Delphi survey into three rounds: brainstorming; narrowing down; and ranking round. Fig. 2 given below illustrates this. Numerous researches have addressed the significance of the Delphi experts [14], [17], [20]. Hence, one of the most decisive requirements in this research is the choice of competent experts. Keeping in mind the principles provided by Schmidt, this study will be conducted in multiple-step iterative process to recognize the experts. Five key steps can be used to summaries this entire technique, as stated in the following Fig. 3.

\section{REVIEW OF THE HiSTORICAL URBAN DEVELOPMENT OF THE CITY OF RIYADH}

In less than half a century, the area of Riyadh has expanded more than a hundred times from a small town surrounded by walls to a modern city that occupies an area of 2435 square kilometers [21]. Existing body of research indicates that Riyadh began its growth and evolution as a modern city at the beginning of the twentieth century. At the beginning of 1900 , the population of the city was approximately 8000 where the people were living in the city that covered an area of almost one square kilometer [22]. They were living a traditional lifestyle that was based on the tribal life. The oil discovery at the end of the 1930s and the production of commercial 
amounts of crude oil in the 1940s started an urban revolution in Riyadh in particular and across the country in general. In1953, King Saud arranged the transference of the government offices from the Holy City of Makkah, which until that time was considered the religious and administrative capital, to Riyadh [1].

This had a significant influence on the growth of both the population and spatial area of Riyadh during the 1950s and1960s [23]. The population increased significantly where it was estimated at 50,000,80,000, 160,000 and 420,000 in 1940, 1950, 1960 and 1972 respectively [22]. The spatial area was estimated at 3, 9, 64 and 85 square kilometers in 1940, 1950, 1960 and 1970 respectively [21]. The population of Riyadh has risen dramatically from 420,000 in the early 1970s to almost 5.2 million people in 2010 and expected to reach 10 million by the year 2020 .

\begin{tabular}{|c|c|}
\hline $\begin{array}{l}\text { Round 1: } \\
\text { Brainstorming }\end{array}$ & $\begin{array}{l}\text { - It is designed to determine whether the list of categories and criteria are comprehensive, } \\
\text { understandable. } \\
\text { Experts are asked to evaluate the list, add another and their comments. } \\
\text { Experts are asked to identify any criteria that are unclear or are included under } \\
\text { inappropriate categories. }\end{array}$ \\
\hline & \\
\hline $\begin{array}{l}\text { Round 2: } \\
\text { Narrowing down }\end{array}$ & $\begin{array}{l}\text { - Experts are once again asked to revise the list based on the feedback and comments } \\
\text { provided during R1. } \\
\text { Experts are asked to evaluate new criteria that are provided from R1. } \\
\text { - Experts are asked to add their comments. }\end{array}$ \\
\hline & \\
\hline $\begin{array}{l}\text { Round 3: } \\
\text { Ranking }\end{array}$ & $\begin{array}{l}\text { Experts are asked to rate the level of importance of each categories and criteria to establish } \\
\text { the priorities. } \\
\text { - The level of importance will be rated through the using a 5-point Likert scale. }\end{array}$ \\
\hline
\end{tabular}

Fig. 2. Delphi technique administration process [18].

\begin{tabular}{|c|c|}
\hline $\begin{array}{l}\text { Step 1: } \\
\text { Prepare KRNW }\end{array}$ & $\begin{array}{l}\text { - Identify relevant disciplines: academics, practitioners, government officials. } \\
\text { - Identify relevant organisations. } \\
\text { - Identify relevant academic and practitioner literature. }\end{array}$ \\
\hline \multicolumn{2}{|c|}{$\downarrow$} \\
\hline $\begin{array}{l}\text { Step 2: } \\
\text { KRNW / names }\end{array}$ & $\begin{array}{l}\text { - Write the names of individuals in relevant disciplines and their organizations. } \\
\text { - Write the names of individuals from academic and practitioner literature. }\end{array}$ \\
\hline \multicolumn{2}{|c|}{$\downarrow$} \\
\hline $\begin{array}{l}\text { Step 3: } \\
\text { Nominate } \\
\text { additional experts }\end{array}$ & $\begin{array}{l}\text { - Contact and meet experts listed in KRNW. } \\
\text { - Ask experts listed in KRNW to nominate other experts. }\end{array}$ \\
\hline \multicolumn{2}{|c|}{$\downarrow$} \\
\hline $\begin{array}{l}\text { Step 4: } \\
\text { Rank experts }\end{array}$ & $\begin{array}{l}\text { - Categorise experts according to appropriate list. } \\
\text { - Rank experts within each list based on their qualifications. }\end{array}$ \\
\hline & \\
\hline $\begin{array}{l}\text { Step 5: } \\
\text { Invite experts }\end{array}$ & $\begin{array}{l}\text { - Invite experts for each round. } \\
\text { - Invite experts in the order of their ranking within their list. } \\
\text { - Stop collecting responses when target size is reached. }\end{array}$ \\
\hline
\end{tabular}

Fig. 3. The main methodology for selecting the experts [14]-[18].

\section{Critical Analysis of the DeVelopment Process of THE CITY OF RIYADH}

The proposed model is categorized into five dimensions: environmental, social, economic, planning and ICT. Therefore, this section is structured into five subsections in order to discuss and critique the urban growth of Riyadh in the light of these five identified dimensions.

\section{A. Environmental Dimension}

This focuses on a number of key issues including climate, energy, and pollution prevention. In Riyadh, one of the most important built environment changes is the replacement of the traditional vernacular house (with internal courtyard) with a western imported dwelling concept known as the "villa" [7]. This had the impact on the wide use of non-environmental friendly air-conditioning technologies to maintain acceptable comfort conditions.

The increase in the numbers of cars as a result of poor planning and the absence of public transport has also resulted in heightened environmental pollution, leading to an increased occurrence of chronic respiratory diseases [9], [24], [25]. During the development process, land was considered as homogenous without regard to topographical features or location [1]. Undoubtedly, this matter has led to the disappearance of many areas of biodiversity and natural habitats [26].

\section{B. Social Dimension}

Al-Hathloul [23], points out that over the last five decades the planning of Riyadh has focused on a series of self-sustained communities along the edges of the city. He notices that this focus has contributed clearly to creating many commercial centers and leisure activities randomly and 
away from the core of the city. This issue influenced the social side in various ways including the disintegration of social connections due to the scattering of neighborhoods that were located near each other.

Al-Hemaidi [7], indicates that the social environment has changed dramatically because of the disappearance of public open spaces that provided the local residents with suitable places for their social activities. Immigration into Riyadh has caused confusion in the mental image of the city and consequently affected the cultural and social identity of the city and its citizens [27], [28]. Immigration occurred in the absence of a clear mechanism to deal with such a large influx. In short, all these social changes, led to the emergence of many social issues including the so-called social and economic deprivation among some strata of society [27].

\section{Economic Dimension}

During the last few decades, the oil wealth has allowed the government to initiate numerous national and urban planning strategies for Riyadh. These strategies were aimed at increasing the living standards and the built environment by all feasible means [1]. However, the authors argue that this mode of urbanization has been adopted with very little awareness of the principles of sustainable economic development that is highlighted within the proposed model, including diversity of economic activities. For instance, the development of Riyadh has been built mainly on the oil wealth regardless of the importance of the other sources that support the economic base such as industry and tourism [29], [30].

Consequently, a number of critical economic issues have emerged such as the provision of a sustainable economy based on a diverse resource base, balance between income and spending and the equitable distribution of the incomes. According to the overall strategic plan of Riyadh, there are several economic challenges facing the development and one of the most important ones is the increase of the proportion of people with low incomes and the reduction of people with middle incomes [31].

\section{Planning Dimension}

Until the end of the 1960s there was no comprehensive plan or strategy for development in the city of Riyadh [32]. Since the beginning of the 1970s, Riyadh has witnessed a number of different urban planning forms and there were several imported schemes, which have been adopted such as Doxiadis and SCET [1], [23], [33].

However, these imported plans failed to control the growth of the city because of the failure to understand the local context of the city [2], [33]. The adoption of the gridiron pattern in Riyadh has led to the expansion of the spatial areas. Gridiron pattern provides urban areas with unbounded growth where the subdivisions can be extended in unsustainable manner in the absence of appropriate decisions [1], [7], [28]. The previous strategies have not taken into account the importance of the public transport system for movement within the city.

\section{E. ICT Dimension}

The importance of ICT has arisen as one of the most valuable tools that must be exploited to pave the way to sustainable cities. In the proposed model the ICT dimension looks at a number of issues that affect the daily life of citizens including their ability to access the technologies and services through a comprehensive broadband network whenever they want to and wherever they are.

Based on the literature review, the paper would argues that this important dimension has been disregarded in most of the studies in the field of sustainable urban planning development in respect of the city of Riyadh. It is very clear from the examination introduced so far that during the development process there were several plans that have been adopted which overlooked the importance of ICT. The focus of the governmental authorities was more on controlling the growth of the population and spatial area rather than connecting the city through ICT to manage the whole city in an integrated way.

\section{Delphi-Based VAlidation Results}

Experts were asked to determine the level of the importance of each dimension of the proposed model for the city of Riyadh. Of the 45 experts, 40 agreed to participate in this research, where 37 experts have completed the first round of Delphi Technique and 35 experts have completed the second and third round. As shown in Fig. 4, the majority of the experts have placed emphasis on the importance of all five dimensions.

Experts rated these dimensions based on the priority of each of them from their individual point of view. The environmental dimension is considered as the most important one whereas the ICT dimension is considered less important. However, all of the five dimensions are located within the range between very important and extremely important.

Table I shows that the mean values for the dimensions of the proposed model are in the range of 4.43 and 4.83 based on a five-point Likert scale, where 1 represented not at all important and 5 represented extremely important. Additionally, standard deviations for all the dimensions are less than 1 and in the range of 0.38 and 0.65 , which means that there is a satisfying consensus. The decrease in the standard deviation means that the experts show a movement toward convergence and consensus [19]-[34].

This section introduces the findings of the Delphi Technique and the most important results that have been reached. Therefore, it has been divided into five subsections to deal with each one of these dimensions in detail. The main aim of this division is to obtain the opinion of experts regarding the proposed model in order to answer the research question, which is how Riyadh can be guided towards more sustainable urban planning development.

TABLE I: THE MEAN AND STANDARD DEVIATION FOR THE DIMENSIONS OF THE PROPOSED MODEL.

\begin{tabular}{|l|c|c|}
\hline Dimension & Mean & $\begin{array}{c}\text { Standard } \\
\text { Deviation }\end{array}$ \\
\hline Social Dimension & 4.6857 & 0.52979 \\
\hline Economic Dimension & 4.6286 & 0.54695 \\
\hline Environmental Dimension & 4.8286 & 0.38239 \\
\hline Planning Dimension & 4.4857 & 0.61220 \\
\hline ICT Dimension & 4.4286 & 0.65465 \\
\hline
\end{tabular}

\section{A. Social Dimension}

The mean values for the categories of social dimension are in the range of 4.11 and 4.83 . The standard deviations for the categories are less than 1 and in the range of 0.45 and 0.83 . Experts are agreed on the importance of these categories and 
they considered health as the most important category as can be seen in Table II.

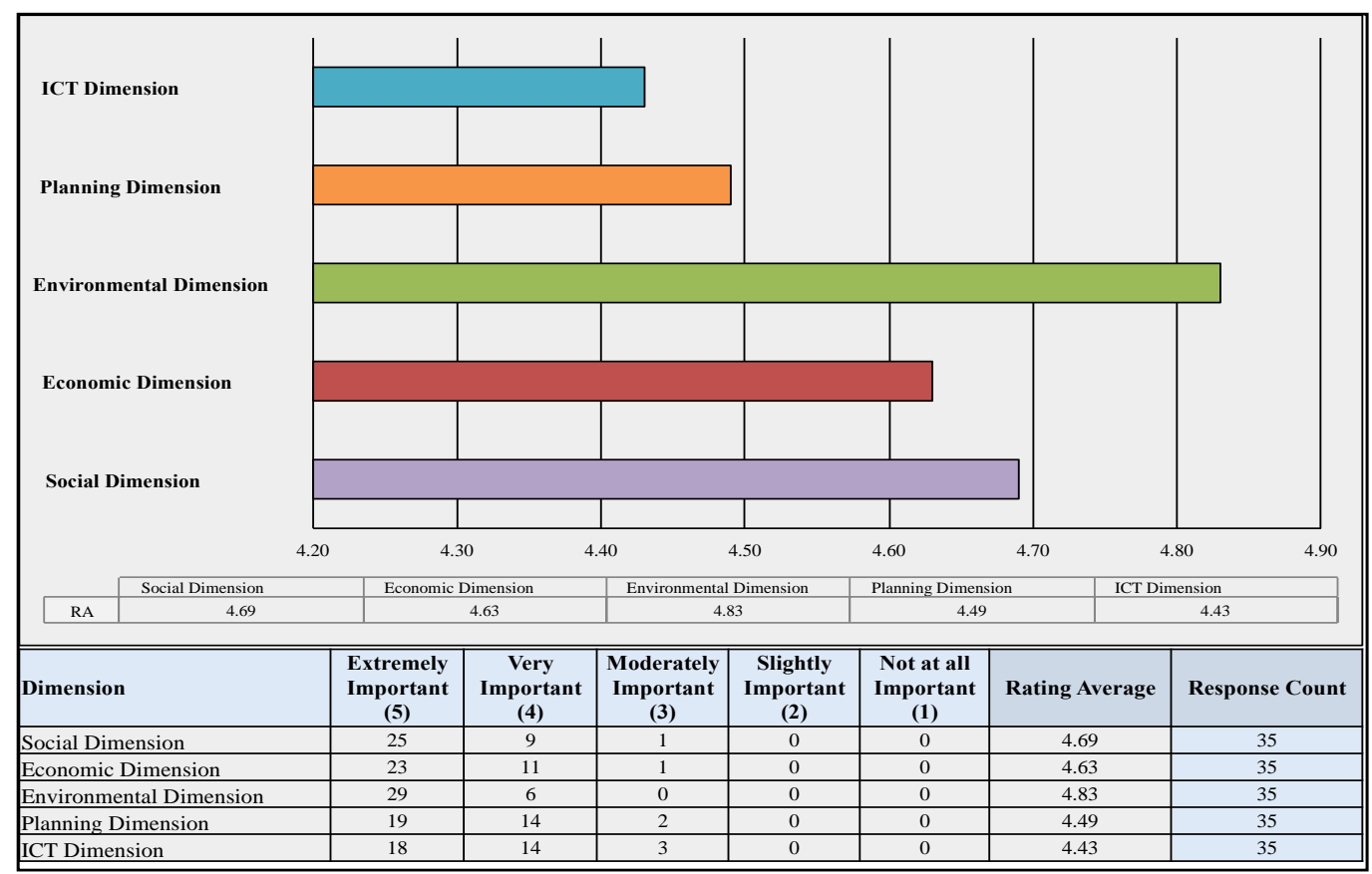

Fig. 2. Rating average of the important level of the dimensions for the proposed model.

TABLE II: THE MEAN AND STANDARD DEVIATION FOR THE SOCIAL DIMENSION

\begin{tabular}{|c|c|c|c|}
\hline Category & Criteria & Mean & $\begin{array}{c}\text { Standard } \\
\text { Deviation }\end{array}$ \\
\hline \multirow{4}{*}{ Health } & & 4.8286 & 0.45282 \\
\hline & $\begin{array}{l}\text { Consideration of health } \\
\text { and safety issues }\end{array}$ & 4.7143 & 0.51856 \\
\hline & \begin{tabular}{|l|} 
Providing medical \\
facilities \\
\end{tabular} & 4.6571 & 0.59125 \\
\hline & $\begin{array}{l}\begin{array}{l}\text { Easy access to health } \\
\text { services }\end{array} \\
\end{array}$ & 4.6286 & 0.59832 \\
\hline \multirow{4}{*}{ Education } & & 4.6286 & 0.54695 \\
\hline & $\begin{array}{l}\text { Providing educational } \\
\text { facilities }\end{array}$ & 4.6571 & 0.53922 \\
\hline & \begin{tabular}{|l|} 
Health and safety within \\
educational environment
\end{tabular} & 4.4857 & 0.56211 \\
\hline & \begin{tabular}{|l|} 
Educational \\
management
\end{tabular} & 4.2000 & 0.63246 \\
\hline \multirow{5}{*}{ Equity } & & 4.2857 & 0.71007 \\
\hline & \begin{tabular}{|l} 
Equitable distribution of \\
services
\end{tabular} & 4.6857 & 0.47101 \\
\hline & \begin{tabular}{|l|}
$\begin{array}{l}\text { Equitable distribution of } \\
\text { income }\end{array}$ \\
\end{tabular} & 4.2857 & 0.62174 \\
\hline & \begin{tabular}{|l|} 
Public participation \\
\end{tabular} & 4.3143 & 0.58266 \\
\hline & Heritage preservation & 4.3143 & 0.63113 \\
\hline \multirow[b]{4}{*}{ Community } & & 4.1143 & 0.83213 \\
\hline & $\begin{array}{l}\text { Community involvement } \\
\text { in decision-making } \\
\end{array}$ & 4.5429 & 0.56061 \\
\hline & $\begin{array}{l}\text { Characteristics of the } \\
\text { population }\end{array}$ & 4.2857 & 0.71007 \\
\hline & $\begin{array}{l}\text { Promoting digital } \\
\text { community }\end{array}$ & 4.1176 & 0.68599 \\
\hline \multirow{6}{*}{ Security } & & 4.5143 & 0.65849 \\
\hline & \begin{tabular}{|l|} 
Natural hazards \\
\end{tabular} & 4.4857 & 0.65849 \\
\hline & Man-made hazards & 4.4857 & 0.65849 \\
\hline & Risk mitigation & 4.6286 & 0.49024 \\
\hline & \begin{tabular}{|l|} 
Risk management \\
\end{tabular} & 4.5143 & 0.56211 \\
\hline & Crime prevention & 4.7143 & 0.45835 \\
\hline
\end{tabular}

TABLE III: THE MEAN AND STANDARD DEVIATION FOR THE ECONOMIC DIMENSION

\begin{tabular}{|c|c|c|c|}
\hline Category & Criteria & Mean & $\begin{array}{c}\text { Standard } \\
\text { Deviation }\end{array}$ \\
\hline \multirow{5}{*}{$\begin{array}{l}\text { Sustainable } \\
\text { Economy }\end{array}$} & & 4.7429 & 0.50543 \\
\hline & \begin{tabular}{|l} 
Enhancement of \\
local economy
\end{tabular} & 4.6857 & 0.47101 \\
\hline & $\begin{array}{l}\text { Diversity of } \\
\text { economic activities }\end{array}$ & 4.4000 & 0.60391 \\
\hline & $\begin{array}{l}\text { Efficient use of } \\
\text { resource }\end{array}$ & 4.5143 & 0.50709 \\
\hline & $\begin{array}{l}\text { Balance between } \\
\text { income and spending }\end{array}$ & 4.3714 & 0.64561 \\
\hline \multirow{6}{*}{$\begin{array}{l}\text { Economic } \\
\text { Growth }\end{array}$} & & 4.2941 & 0.67552 \\
\hline & \begin{tabular}{|l} 
Developing new \\
investment
\end{tabular} & 4.3143 & 0.71831 \\
\hline & $\begin{array}{l}\begin{array}{l}\text { Promoting local } \\
\text { industry }\end{array} \\
\end{array}$ & 4.5714 & 0.50210 \\
\hline & Business facilities & 4.2286 & 0.64561 \\
\hline & Economic capacity & 4.2571 & 0.56061 \\
\hline & $\begin{array}{l}\text { Providing healthy } \\
\text { economic } \\
\text { environment }\end{array}$ & 4.6000 & 0.55307 \\
\hline \multirow{5}{*}{ Employment } & & 4.5714 & 0.60807 \\
\hline & Healthy employment & 4.4000 & 0.60391 \\
\hline & \begin{tabular}{|l|}
$\begin{array}{l}\text { Employment } \\
\text { opportunities }\end{array}$ \\
\end{tabular} & 4.6571 & 0.48159 \\
\hline & $\begin{array}{l}\text { Employment } \\
\text { prospect }\end{array}$ & 4.1714 & 0.61767 \\
\hline & Work environment & 4.4000 & 0.60391 \\
\hline \multirow{7}{*}{ Employees } & & 4.4000 & 0.60391 \\
\hline & $\begin{array}{l}\text { Skills and } \\
\text { qualifications }\end{array}$ & 4.6571 & 0.53922 \\
\hline & Effective training & 4.6000 & 0.55307 \\
\hline & Vocational guidance & 4.2857 & 0.62174 \\
\hline & Motivation & 4.5000 & 0.50752 \\
\hline & \begin{tabular}{|l}
$\begin{array}{l}\text { Employees } \\
\text { participation }\end{array}$ \\
\end{tabular} & 4.1714 & 0.61767 \\
\hline & Working efficiency & 4.5143 & 0.50709 \\
\hline \multirow{6}{*}{ Productivity } & & 4.2857 & 0.57248 \\
\hline & Quality & 4.6857 & 0.47101 \\
\hline & Cost efficiency & 4.5714 & 0.60807 \\
\hline & Efficient pricing & 4.3143 & 0.67612 \\
\hline & \begin{tabular}{|l} 
Delivery \\
\end{tabular} & 4.1143 & 0.63113 \\
\hline & Accessibility & 4.1714 & 0.70651 \\
\hline
\end{tabular}




\section{B. Economic Dimension}

The mean values for the categories of economic dimension are in the range of 4.29 and 4.74. The standard deviations for the categories and its criteria are less than 1 and in the range of 0.47 and 0.71 . The category of sustainable economy is considered as the most important one whereas the category of productivity is considered less important, keeping in mind that all of the categories are located within the range between very important and extremely important. Table III shows the mean values and the standard deviations for all the categories and criteria of economic dimension.

\section{Environmental Dimension}

As is the case with previous dimensions, the standard deviations for all the categories of environmental dimension are less than 1 and in the range of 0.38 and 0.59 . It means that a satisfactory consensus has been achieved. Furthermore, the mean values for the categories are in the range of 4.34 and 4.83. Table IV displays the mean values and standard deviations for the categories of environmental dimension in addition to their criteria.

TABLE IV: THE MEAN AND STANDARD DEVIATION FOR THE ENVIRONMENTAL DIMENSION

\begin{tabular}{|c|c|c|c|}
\hline Category & Criteria & Mean & $\begin{array}{c}\text { Standard } \\
\text { Deviation }\end{array}$ \\
\hline \multirow{5}{*}{ Climate } & & 4.6000 & 0.49705 \\
\hline & Global warming & 4.4571 & 0.61083 \\
\hline & Carbon emissions & 4.7714 & 0.42604 \\
\hline & Solar radiation & 4.3429 & 0.63906 \\
\hline & Flood risk issues & 4.5429 & 0.61083 \\
\hline \multirow{6}{*}{ Ecology } & & 4.3429 & 0.59125 \\
\hline & $\begin{array}{l}\text { Ecological } \\
\text { assessment }\end{array}$ & 4.2857 & 0.62174 \\
\hline & Biodiversity & 4.2857 & 0.51856 \\
\hline & Flora / Fauna & 4.2857 & 0.57248 \\
\hline & $\begin{array}{l}\text { Ecological } \\
\text { appraisal }\end{array}$ & 4.2000 & 0.67737 \\
\hline & Ecological survey & 4.3429 & 0.63906 \\
\hline \multirow{5}{*}{ Energy } & & 4.6857 & 0.52979 \\
\hline & Passive design & 4.2286 & 0.68966 \\
\hline & Energy efficiency & 4.5143 & 0.50709 \\
\hline & $\begin{array}{l}\text { Energy } \\
\text { consumption }\end{array}$ & 4.6286 & 0.49024 \\
\hline & $\begin{array}{l}\text { Energy } \\
\text { management }\end{array}$ & 4.6286 & 0.54695 \\
\hline \multirow{6}{*}{ Resource } & & 4.7429 & 0.50543 \\
\hline & Resource recycling & 4.4857 & 0.70174 \\
\hline & $\begin{array}{l}\text { Resource } \\
\text { efficiency }\end{array}$ & 4.5714 & 0.55761 \\
\hline & $\begin{array}{l}\text { Use of local } \\
\text { resource }\end{array}$ & 4.4857 & 0.70174 \\
\hline & $\begin{array}{l}\text { Use of renewable } \\
\text { resource }\end{array}$ & 4.4857 & 0.65849 \\
\hline & $\begin{array}{l}\text { Resource } \\
\text { management }\end{array}$ & 4.6286 & 0.54695 \\
\hline \multirow{6}{*}{ Pollution } & & 4.8286 & 0.38239 \\
\hline & $\begin{array}{l}\text { Pollution } \\
\text { assessment }\end{array}$ & 4.5429 & 0.74134 \\
\hline & Noise and waste & 4.3429 & 0.63906 \\
\hline & Water pollution & 4.6571 & 0.48159 \\
\hline & $\begin{array}{l}\text { Pollution } \\
\text { prevention }\end{array}$ & 4.7143 & 0.45835 \\
\hline & Air quality & 4.7429 & 0.44344 \\
\hline
\end{tabular}

\section{ICT Dimension}

Experts have showed a movement towards a satisfying consensus and they agreed that ICT should be considered within the model. In this dimension, the focus was mainly on the categories rather than the criteria because of that fact the
ICT approach has not been introduced clearly yet within Saudi Arabian cities. As can be seen in Table 5 the mean values of the ICT categories are in the range of 4.43 and 4.66 where all of them located within the range between very important and extremely important. The standard deviations for the categories are also less than 1 and in the range of 0.50 and 0.61 .

TABLE V: THE MEAN AND STANDARD DEVIATION FOR THE ICT DIMENSION.

\begin{tabular}{|l|c|c|}
\hline Criteria & Mean & $\begin{array}{c}\text { Standard } \\
\text { Deviation }\end{array}$ \\
\hline $21^{\text {st }}$ century skill outcomes & 4.5143 & 0.61220 \\
\hline Universal access to technology & 4.5429 & 0.56061 \\
\hline Access to services and resources 24/7 & 4.6571 & 0.53922 \\
\hline ICT management & 4.5429 & 0.50543 \\
\hline Technological and institutional aspects & 4.4286 & 0.60807 \\
\hline
\end{tabular}

\section{E. Planning Dimension}

During the process of Delphi Technique, experts have agreed the importance of planning dimension as an independent dimension. They confirm that it must be added to the pillars of sustainable development (social, economic and environmental) recognized since 1987 by the Brundtland Commission. The mean values of the categories of planning dimension are in the range of 4.51 and 4.77. The standard deviations are less than 1 and in the range of 0.42 and 0.65 . The mean values and standard deviations for the categories of the planning dimension and their criteria are illustrated in Table VI.

TABLE VI: The MEAn AND StANDARd DEVIATION For THE PlanNing DIMENSION

\begin{tabular}{|c|c|c|c|}
\hline Category & Criteria & Mean & $\begin{array}{c}\text { Standard } \\
\text { Deviation }\end{array}$ \\
\hline \multirow{7}{*}{ Land Use } & & 4.7714 & 0.42604 \\
\hline & $\begin{array}{l}\text { Distribution of } \\
\text { land use }\end{array}$ & 4.6857 & 0.52979 \\
\hline & $\begin{array}{l}\text { Residential } \\
\text { schemes }\end{array}$ & 4.4000 & 0.60391 \\
\hline & Public services & 4.4000 & 0.55307 \\
\hline & Open spaces / park & 4.5143 & 0.65849 \\
\hline & $\begin{array}{l}\text { Effective use of } \\
\text { land }\end{array}$ & 4.5429 & 0.56061 \\
\hline & Land ownership & 4.4571 & 0.65722 \\
\hline \multirow{4}{*}{ Infrastructure } & & 4.6571 & 0.48159 \\
\hline & $\begin{array}{l}\text { Green } \\
\text { infrastructure }\end{array}$ & 4.3143 & 0.75815 \\
\hline & $\begin{array}{l}\text { Infrastructure } \\
\text { efficiency }\end{array}$ & 4.6286 & 0.49024 \\
\hline & $\begin{array}{l}\text { Infrastructure } \\
\text { management }\end{array}$ & 4.6286 & 0.59832 \\
\hline \multirow{5}{*}{ Transport } & & 4.5143 & 0.65849 \\
\hline & $\begin{array}{l}\text { Consideration of } \\
\text { traffic issues }\end{array}$ & 4.5714 & 0.55761 \\
\hline & $\begin{array}{l}\text { Public } \\
\text { transportation }\end{array}$ & 4.6286 & 0.54695 \\
\hline & $\begin{array}{l}\text { Transport } \\
\text { facilities }\end{array}$ & 4.4286 & 0.65465 \\
\hline & Transport policies & 4.5714 & 0.65465 \\
\hline \multirow{7}{*}{ Management } & & 4.6000 & 0.60391 \\
\hline & Monitoring & 4.4857 & 0.61220 \\
\hline & Control & 4.4571 & 0.65722 \\
\hline & Operation & 4.4412 & 0.66017 \\
\hline & Maintenance & 4.4118 & 0.65679 \\
\hline & $\begin{array}{l}\text { Governmental } \\
\text { rules and } \\
\text { regulations }\end{array}$ & 4.3143 & 0.63113 \\
\hline & $\begin{array}{l}\text { Planning policies } \\
\text { and legislations }\end{array}$ & 4.3714 & 0.64561 \\
\hline
\end{tabular}




\section{DISCUSSION}

The authors argue that the process of urban development during the last few decades has been followed with minimum understanding and recognition of social, economic and environmental issues. Although the Ministry of Municipal and Rural Affairs developed urban boundaries (MEDSTAR) for the city of Riyadh to manage and control the growth of the city, subdivisions continue to expand under the influence of various factors, such as landowner's projects and ambitions and the absence of required decisions from the related authorities. Furthermore, the MEDSTAR scheme does not provide a long-term integrated approach for sustainable growth [35]-[36]. A number of issues, including the historical development of the city, limitations of previous plans, society characteristics and the local context have informed the development of a new model of sustainable urban planning. The latter encourages citizens to understand the cultural values of communities and the importance of the concept of "place".

Most of the results and findings reached through the use of Delphi Technique have emphasized the need for the proposed model due to the existence of many issues, obstacles and challenges, which must be dealt with and managed in an informed and integrated way. Therefore, the significance of having such an effective sustainable urban planning development model has emerged as a critical issue. The paper argues that such a model would deliver substantial benefits to communities despite potential difficulties and obstacles. During the Delphi process, experts were asked to express their opinions in respect to the proposed model and as a result a number of changes have been introduced. For instance, new criteria have been recommended by experts to be included within the proposed model such as governmental rules, regulations and legislations. Experts have reached a consensus regarding the contents of the proposed model and emphasized the importance of such as model being implemented in the city of Riyadh. They confirm that the implementation of such model will help to guide the city to a more sustainable future.

\section{CONCLUSIONS AND FUTURE WORK}

The aim of this paper was to give a comprehensive review of the current state of urban planning in the city of Riyadh. The paper argues that Riyadh has developed in an unsustainable manner due to a number of complex factors. The proposed model provides an important tool to achieve sustainability in the city. In this research, the Delphi Technique was used to gather experts' opinion regarding the proposed model in order to address the underpinning research question: Can the growth of Riyadh City be managed sustainably through an adapted sustainable urban planning model? It is recommended by experts that the five dimensions should be taken into account on the same level of the importance and equally in order to achieve the sustainability for the city of Riyadh. The average ratings of the dimensions are located within the range between very important and extremely important, which means that there is a high level of consensus among those experts.

The authors would like to acknowledge two limitations that presently form the scope for follow on work: (a) the lack of validation of the proposed model, (b) the need to establish a weighting system for the proposed categories and criteria. The latter is currently addressed by the use of Analytical Hierarchy Process (AHP) technique and involves a follow on consultation with the experts. Once the weighting system established a full validation of the model will be carried out on the city of Riyadh. These new developments will be reported in follow on publications.

\section{REFERENCES}

[1] F. A. Mubarak, "Urban growth boundary policy and residential suburbanization: Riyadh, Saudi Arabia," Habitat International, vol 28, no. 4, pp. 567-591, 2004.

[2] S. B. Garba, "Managing urban growth and development in the Riyadh metropolitan area, Saudi Arabia," Habitat International, vol. 28, no. 4 pp. 593-608, 2004.

[3] I. M. Al-But'hie and M. A. Eben Saleh, "Urban and industrial development planning as an approach for Saudi Arabia: the case study of Jubail and Yanbu," Habitat International, vol. 26, no. 1, pp. 1-20, 2002.

[4] A. R. Awad and M. T. Aboul-Ela, "Urban planning for low-income groups with developed optimization models," Advances in Engineering Software, vol. 34, no. 10, pp. 607-619, 2003.

[5] WCED. (1987). Development and international co-operation environment, in report of the world commission on environment and development, Unite Nations. [Online]. Available: http://www.un-documents.net/a42-427.htm

[6] W. Vanessa, "The planned city sweeps the poor away...': Urban planning and 21 st century urbanisation," Progress in Planning, vol. 72, no. 3, pp. 151-193, 2009

[7] W. K. Al-Hemaidi, "The metamorphosis of the urban fabric in Arab-Muslim City: Riyadh, Saudi Arabia," Journal of Housing and the Built Environment, vol. 16, no. 2, pp. 179-201, 2001.

[8] M. El-batran, Arab Environment, Future Chhallenges - Urbanization, in Report of the Arab Forum for Environment and Development 2008, AFED: Beirut, Lebanon.

[9] A. Rizzo, "Metro Doha," Cities, vol. 29, no. 5, pp. 291-350, 2012.

[10] G. Assefa et al., "Environmental assessment of real estates - where natural and social sciences meet: the case of ecoeffect," presented at the 2005 World Sustainable Building Conference, Tokyo, September 2005 (SB05Tokyo) pp.27-29

[11] J. T. San-José et al., "Approach to the quantification of the sustainable value in industrial buildings," Building and Environment, vol. 42, no. 11, pp. 3916-3923, 2007

[12] K. C. D. Grace, "Sustainable construction - the role of environmental assessment tools," Journal of Environmental Management, vol. 86, no. 3, pp. 451-464, 2008.

[13] A. Haapio and P. Viitaniemi, "A critical review of building environmental assessment tools," Environmental Impact Assessment Review, vol. 28, no. 7, pp. 469-482, 2008

[14] C. Okoli and S. D. Pawlowski, "The Delphi method as a research tool: an example, design considerations and applications," Information \& Management, vol. 42, no. 1, pp. 15-29, 2004.

[15] F. Hasson, S. Keeney, and H. McKenna, "Research guidelines for the Delphi survey technique," Journal of Advanced Nursing, vol. 32, no. 4 , pp. 1008-1015, 2000.

[16] S. J. Van Zolingen and C. A. Klaassen, "Selection processes in a Delphi study about key qualifications in senior secondary vocational education," Technological Forecasting and Social Change, vol. 70, no. 4, pp. 317-340, 2003.

[17] R. Schmidt et al., "Identifying software project risks: an international Delphi study," Journal of Management Information Systems, vol. 17, no. 4, pp. 5-36, 2001.

[18] C. Powell, "The Delphi technique: myths and realities," Journal of Advanced Nursing, vol. 41, no. 4, pp. 376-382, 2003.

[19] L. A. Vidal, F. Marle, and J. C. Bocquet, "Using a Delphi process and the Analytic Hierarchy Process (AHP) to evaluate the complexity of projects," Expert Systems with Applications, vol. 38, no. 5, pp. 5388-5405, 2011.

[20] M. R. Geist, "Using the Delphi method to engage stakeholders: a comparison of two studies," Evaluation and Program Planning, vol. 33, no. 2, pp. 147-154, 2010.

[21] High Commission for the Development of ArRiyadh. ArRiyadh Urban Indicators $2009 / 1430$ H. 2010 [Online]. Available: 
http://www.ada.gov.sa/Eng/Ab-Arriyad/Content/getdocument.aspx?f= /openshare/Eng/Ab-Arriyad/Content/AboutArRiyadh_21.doc_cvt.htm

[22] Riyadh Municipality. (2011). Riyadh Development. [Online]. Available:

http://www.alriyadh.gov.sa/en/alriyadh/Pages/development_of_popul ation.aspx.

[23] S. Al-Hathloul, Riyadh Architecture in One Hundred Years, Articles and Lectures on Architectural, 2003.

[24] F. B. Chaaban, Arab Environment, Future Chhallenges - Air Quality, in Report of the Arab Forum for Environment and Development, AFED Beirut, Lebanon. pp. 45-62, 2008.

[25] S. A. Al-Fouzan, "Using car parking requirements to promote sustainable transport development in the Kingdom of Saudi Arabia," Cities, vol. 29, no. 3, pp. 201-211, 2012.

[26] National Commission for Wildife Conservation and Development, the national strategy for conservation of biodiversity in the kingdom of saudi arabia, in Convention on Biological Diversity, Riyadh. pp. 94 2005.

[27] M. A. E. Saleh, "The changing image of arriyadh city: the role of socio-cultural and religious traditions in image transformation," Cities, vol. 18 , no. 5, pp. 315-330, 2001.

[28] K. N. Mandeli, "The realities of integrating physical planning and local management into urban development: A case study of Jeddah, Saudi Arabia," Habitat International, vol. 32, no. 4, pp. 512-533, 2008.

[29] M. A. E. Saleh, "The integration of tradition and modernity: a search for an urban and architectural identity in arriyadh, the capital of Saudi Arabia," Habitat International, vol. 22, no. 4, pp. 571-589, 1998.

[30] J. Gamboa. (2008). City expanding to the desert horizon: Riyadh's problem of explosive growth and urban sprawl. Geography. [Online]. Available: http://jpgamboa.com/riyadhsprawl.pdf.

[31] High Commission for the Development of Arriyadh. Economic Development. 2003.2 [Online] Available: http://www.ada.gov.sa/Eng/ADA/Left/PlanProj/More/getdocument.as px?f=/openshare/Eng/ADA/Left/PlanProj/More/Economic-Developm ent1.doc_cvt.htm.

[32] A. N. A. Fassam and A. M. Qhtani, "ArRiyadh geospatial urban information system and metropolitan development strategy for ArRiyadh," in presented at Esri International User Conference, High Commission for the Development of Arriyadh: San Diego, CA, 2011.

[33] M. H. Alkhabbaz, "Development of Good Architecture in the case of Arriyadh Development Authority, Saudi Arabia," Department of Architecture, Massachusetts Institute of Technology, 2010.

[34] D. L. Bryant and M.D. Abkowitz, "Estimation of terrestrial chemical spill risk factors using a modified Delphi approach," Journal of Environmental Management, vol. 85, no. 1, pp. 112-120, 2007.
[35] D. A. Middleton, "Growth and Expansion in Post-War Urban Design Strategies: C. A. Doxiadis and the First Strategic Plan for Riyadh Saudi Arabia (1968-1972)," Academic Faculty, Georgia Institute of Technology, 2009

[36] S. Al-Hathloul and M. A. Mughal, "Urban growth management-the Saudi experience," Habitat International, vol. 28, pp. 609-623, 2004.

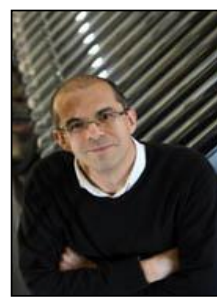

Yacine Rezgui is a BRE (Building Research Establishment) Chair in 'Building Systems and Informatics'. He is a qualified architect with an MSc (Diplôme d'Etudes Approfondies) in "Building Sciences" (obtained from Université Jussieu - Paris 6 ) and $\mathrm{a} \mathrm{PhD}$ in Computer Science applied to the construction industry, obtained from ENPC (Ecole Nationale des Ponts et Chaussées). He has over 100-refereed publications, which appeared in international journals such as Knowledge Engineering Review, Information Sciences, Computer-Aided Design, Journal of Operational Research Society, and Interacting with Computers.

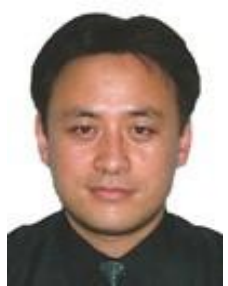

Haijiang $\mathbf{L i}$ is a lecturer (Engineering Informatics \& Structural Applications) working in the BRE Institute of Sustainable Engineering, Engineering School, Cardiff University. His main research interest lies on Advanced and Innovative Computing supported large scale systems integration and decision making applied in buildings (BIM) and district / city infrastructure. Dr. Haijiang LI has been working on several research projects (EPSRC / TSB / A4B / EU FP7, total cost about $£ 16 \mathrm{M}$, about 20 full time research associates and $\mathrm{PhD}$ researchers). He has about 50 various peer reviewed publications.

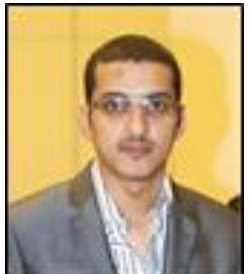

Ali AlQahtany is one of the $\mathrm{PhD}$ candidates in School of Engineering at Cardiff University. His main research interest lies on the Sustainable Urban Planning Development field. He obtained his master degree from School of Engineering at University of Birmingham in Construction Management subject in 2010. He obtained his bachelor degree from Architecture and Planning Department from King Saud University (Saudi Arabia) in 2008 in the Planning and Urban Design Engineer. 